\title{
Medicinally important and edible species of genus Lactarius from Garhwal Himalaya, India
}

\author{
Joshi S, Vishwakarma MP, Mahar R and Bhatt RP
}

Department of Botany and Microbiology, H. N. B. Garhwal University, Srinagar Garhwal, Uttarakhand 246174, India

Joshi S, Vishwakarma MP, Mahar R, Bhatt RP 2013 - Medicinally important and edible species of genus Lactarius from Garhwal Himalaya, India. Mycosphere 4(4), 714-720, Doi 10.5943/mycosphere/4/4/8

\begin{abstract}
This paper reports medicinally important and edible species of ectomycorrhizal genus Lactarius collected during the monsoon season between 2006-2009, in the elevation range of 350 to $3200 \mathrm{~m}$ above sea level from district Pauri Garhwal and Tehri Garhwal of Garhwal Himalaya. It includes description of $L$. hygrophoroides var. hygrophoroides, $L$. piperatus var. piperatus, $L$. scrobiculatus var. scrobiculatus,L. subindigo, L. subpurpureus and $L$. volemus var. volemus. Among these six species, L. piperatus var. piperatus and $L$. volemus var. volemus are medicinally important and other species are edible in Garhwal region or reported edibles from other parts of the world. The medicinal properties are compiled on the basis of information gathered by literature review. This report provides new information on edible and medicinally important species of Garhwal region.
\end{abstract}

Key words - Ectomycorrhizal - Garhwal - Macrofungi - Russulaceae

\section{Introduction}

Lactarius (Russulaceae) is a medicinally important and promising edible, macrofungal, ectomycorrhizal genus. It is popularly known as 'milk' cap or 'chuo' in native villages of Garhwal Himalaya. It is low in fat and a good source of digestible protein, fiber, vitamin and mineral. Lactarius resimus and L. scrobiculatus are highest prized Lactarii in the Russian market (Singer 1949). In Africa some species (L. edulis, L. gymnocarpoides, L. longisporus, L. xerampelinus) are reported edibles from Zimbabwe (Verbeken et al. 2000). The pharmacologically important properties of genus Lactarius are also incredible. The chloroform extract of the fruiting bodies of $L$.

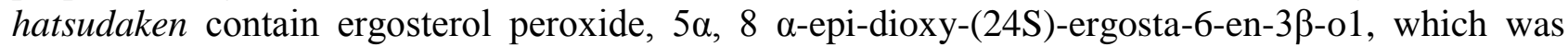
found to be active against HIV replication in C8166 cells in vitro (Zhang et al. 2007). L. vellereus is a natural source of antimutagen with potential pharmacological application in cancer prevention. Methanol extract of $L$. vellereus is highly protective against 2-amino-3-methylimidazo (4,5-f) quinoline mutagen-induced DNA damage in human derived cells (Mlinaric et al. 2004). A 14.6-kDa RNase was isolated from dried fruiting bodies of L. flavidulus and mycelial culture has anti-cancer properties, which suppress the proliferation of cancerous cells. RNase has been also shown to inhibit reverse transcription activity of HIV-1 virus (Wu et al. 2012).

In this study of Lactarius from Garhwal Himalaya during 2006-2009 (Joshi et al. 2012) out of 47 taxa collected, six species were found to have edible and pharmacological importance. These species can be used for the food and medicinal benefits of locals of Garhwal. 


\section{Study Area}

Garhwal Himalaya is a hot-spot of biodiversity situated in Western part of Central Himalaya (latitude $29^{\circ} 31^{\prime}$ ' 9" to $31^{\circ} 26^{\prime} 5^{\prime \prime} \mathrm{N}$, longitude $77^{\circ} 33^{\prime} 5^{\prime \prime}$ to $80^{\circ}$ 6' 0" E) (Fig. 1). Wide altitudinal range, rapid change in altitudinal gradient, even at small distances, and high endemism make it interesting for the study of macrofungal diversity. Administratively Garhwal Himalaya comprises seven districts namely Chamoli, Rudraprayag, Pauri Garhwal, Tehri Garhwal, Uttarkashi, Haridwar and Dehradun. Forests of Garhwal Himalaya range from lower Sivaliks to high altitude temperate forest belts (350 to $3200 \mathrm{~m}$.a.s.l.). The forest flora of this region mainly comprises Quercus semecarpifolia, $Q$. floribunda, $Q$. leucotrichophora, Rhododendron arboreum, Abies pindrow, Cupressus torulosa, Cedrus deodara, Pinus roxburghii, Shorea robusta, Anogeissus latifolia, Holoptelea integrifolia, Acacia catechu, Dalbergia sissoo and Spondias pinnata.

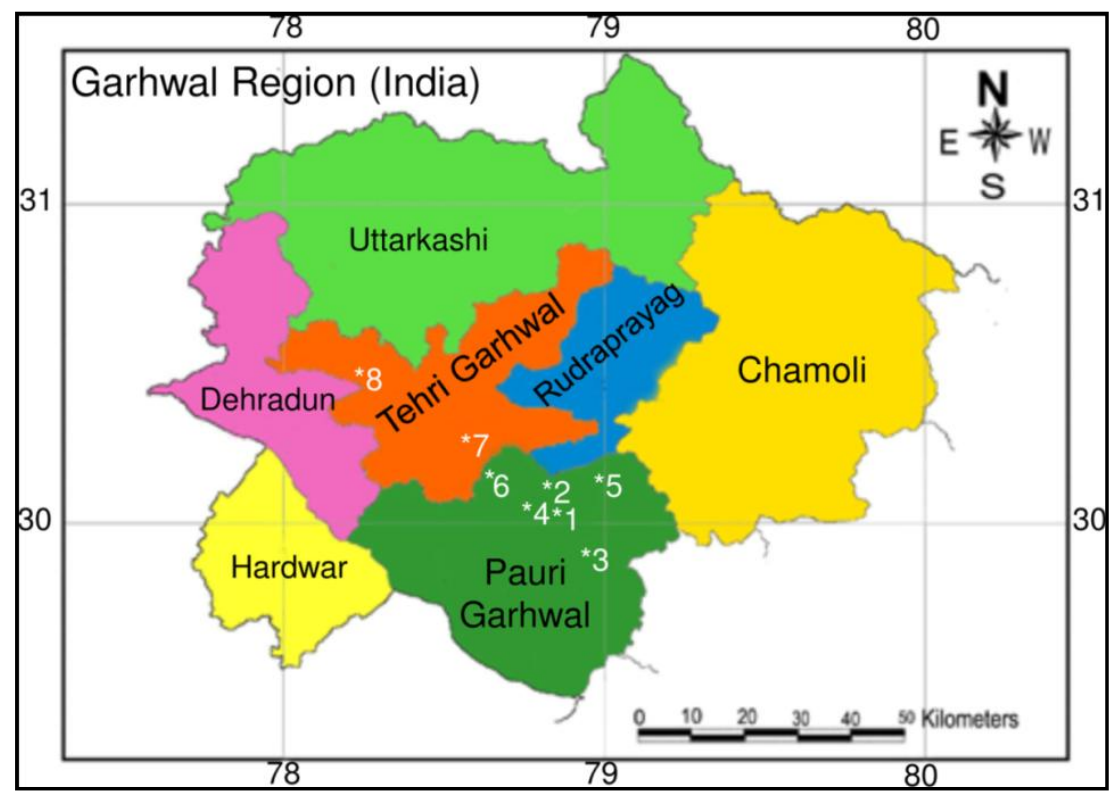

Fig. 1 - Map ofGarhwal Himalaya showing collection sites 1Bubakhal, 2Chaubattakhal, 3Bharsar, 4Nagdev-Jhandidhar, 5Khirsu, 6Dandapani, 7Chandrabadni, 8Surkanda devi.

\section{Materials \& Methods}

Specimens were collected from different forest belts of Garhwal Himalaya from 2006 to 2009. Macroscopic details of the samples including size, shape, odour, colour change on cutting and bruising, chemical spot test, taste and ecological characters were recorded in the field. While collecting,the samples were carefully handled to prevent damage. All samples were collected as described previously in properly aerated paper bags (Largent 1977a). Samples were further described, photographed and dried as recommended by Halling (1996). Microscopic examination for spore identification was performed at 1000-1500x magnification (Largent et al. 1977b). Species identification was done with the help of relevant publications (Heilmann-Clausen et al. 1998, Hesler\& Smith 1979, Singer 1986). Edible and medicinally important specimens were identified on the basis of information collected either from native villagers or worldwide literature review. Species are arranged in alphabetic order with details of their macroscopic and microscopiccharacters including morphology of basidiomes, ecology/habitat and spore characters. Voucher specimens are deposited in the HNB (GUH) herbarium, Srinagar Garhwal, Uttarakhand, India. 


\section{Results}

The medicinally important and edible specimens of genus Lactarius collected from different forest belts of Garhwal Himalaya are discussed.

Lactarius hygrophoroidesvar.hygrophoroides Berk. \& M.A. Curtis, Ann. Mag. Nat. Hist. 3rd Ser. 4: $293,1859$.

Fig. $2 \mathrm{a}$

Pileus 50-100 mm in diam., convex when young becoming plane with maturity, centrally depressed; surface dry and usually with a velvety sheen, azonate, at times rugose, golden yellow to yellowish brown; margin inrolled when young becoming plane with age, smooth; pilear surface turns pale olive with $\mathrm{KOH}$. Lamellae adnate to decurrent, distant, narrow to moderately broad, whitish to pale, not staining, lamellulae present in 1-2 tiers; edges even. Stipe 30-65 × 10-26 mm, short, solid, firm, more or less concolorous with the pileus, glabrous or with an unpolished velvety sheen. Context rigid but brittle, pallid. Latex white, unchanging, copious. Taste mild. Odour indistinctive. Spore deposit white. Spores $6.5-10.0 \times 6.0-7.5 \mu \mathrm{m}$, broadly ellipsoid to subglobose, amyloid, coarsely reticulate, ornamentation of thick lines and a few isolated warts, ornamentation 0.2-0.4 $\mu \mathrm{m}$ high (Fig. 3a). Habitat - commonly found on humicolous soil in association with Quercus leucotricophora,Lyonia ovalifolia, Myrica esculenta, and Rhododendron arboreum. Edible and consumed in Garhwal.

Specimens examined - Pauri Garhwal, Bubakhal, 2 August 2007 (GUH M-25196) and Chaubattakhal, 4 August 2008 (GUH M-25440).

Lactarius piperatusvar.piperatus(Fr.) S.F. Gray, Nat. Arr. Brit. Pl. 1: 623. 1821.

Fig. $2 b$

Pileus $40-140 \mathrm{~mm}$ in diam., convex with depressed center, broadly infundibuliform to uplifted at maturity; surface dry, smooth, cracked, often concentrically wrinkled towards margin, white to yellowish white or cream, sometimes with brownish tinge at maturity; margin incurved to decurved, often plane to uplifted at maturity; pilear surface turns pale magenta with $\mathrm{KOH}$. Lamellae crowded, repeatedly forked, white, becoming yellowish white with age. Stipe $25-75 \times$ 5-16 mm, central to eccentric, equal in diam., throughout or slightly tapering downwards, solid at first, hollowing with age, dry, white, becoming yellowish white with age, smooth. Context solid, white, slowly yellowish white on exposure to air. Latex white, turns yellowish white on drying or staining gills, yellowish white. Taste acrid to very acrid. Odour not distinctive. Spore print white. Spores6.0-8.8 $\times 4.0-6.7 \mu \mathrm{m}$, broadly ellipsoid to subglobose, ornamentation amyloid, composed of minute warts, ridges, less than $0.5 \mu \mathrm{m}$ high, mostly isolated, sometimes aligned forming an incomplete reticulum (Fig. 3b). Habitat - commonly found scattered to gregarious, on humicolous soil in association with Quercus leucotrichophora, Cedrus deodara, Myrica esculenta, Pinus roxburghii, and Rhododendron arboreum. Medicinally important.

Specimens examined - Bharsar, 3 October 2007 (GUH M-25307) district Pauri Garhwal and Chandrabadni, 7 September 2009 (GUH M-25639) from district Tehri Garhwal.

Lactarius scrobiculatus var. scrobiculatus (Fr.) Fr., Epicr. Syst. Mycol.334, 1838. Fig. 2c Pileus 60-200 mm in diam., convex with central depression, distinctly zoned; surface in center smooth or finely squamulose, increasingly pubescent to hairy towards margin, dry to viscid in centre, glutinous towards margin, whitish chrome or cream to buff-yellow, mostly with distinct honey coloured zones, with age or when bruised turning more honey coloured; margin incurved becoming straight or wavy with age, entire. Lamellae adnate to decurrent, medium crowded to medium broad, sometimes forked near the stipe, whitish chrome to pale cream to cream. Stipe 25$70 \times 15-35 \mathrm{~mm}$, cylindric to barrel-shaped; surface whitish or pale cream, with scattered to numerous cream to warm buff, yellowish brown pits of irregular shape. Context firm, hollow in the stipe, whitish, when cut becoming lemon-yellow near the surface of cap and stipe. Latex white, after a short while sulphur-yellow, abundant. Taste unpleasant and acrid. Odour fruity-acidic. Spore deposit pale cream. Spores 7.0-9.6 $\times 6.0-7.2 \mu \mathrm{m}$, broadly ellipsoid to ellipsoid, ornamentation up to $1 \mu \mathrm{m}$ high, of short ridges and elongate or irregular warts, not reticulate but 
often in a partly spirallic pattern; plageinamyloid (Fig. 3c). Habitat -solitary, scattered sometimes gregarious, under conifers, in association with Cedrus deodara and Cupressus torulosa. May be edible in Garhwal, but consumed in some parts of the world.

Specimens examined - Nagdev - Jhandidhar, 28 September 2007 (GUH M-25297) district Pauri Garhwal.

Lactarius subindigoVerbeken \& E. Horak, Aust. Syst. Bot. 13: 651, 2000.

Fig. $2 d$

Pileus 55-70 mm in diam., at first convex with depressed center, later umbilicate when mature; surface viscid when moist, zonate, medium greenish to medium blue with silvery lusture, sometimes medium yellow with age; margin strongly incurved when young, plane when mature. Lamellae decurrent, crowded, lamellulae in several rows, light to medium greenish blue, deep to very deep greenish blue after bruising. Stipe $25-40 \times 6-10 \mathrm{~mm}$, cylindrical or gradually tapered towards base, concolorous with pileus, scrobiculate, hollow. Context brittle, light greenish to light blue. Latex dark to deep greenish blue, unchanging. Spore print yellowish white. Spores $7.0-8.5 \times$ 5.5-7.2 $\mu \mathrm{m}$, broadly ellipsoid, amyloid, ornamentation up to $0.5 \mu \mathrm{m}$ high, composed of blunt ridges forming partial to incomplete reticulation, isolated warts abundant (Fig. 3d). Habitat - solitary, scattered on humicolous soil, associated with Quercus leucotricophora. Edible but not consumed in Garhwal.

Specimens examined-Khirsu, 11 September 2007(GUH M-25243) district Pauri Garhwal and Surkanda Devi forest belt, 15 September 2008 (GUH M-25,635) district Tehri Garhwal.

Lactarius subpurpureus Peck, Ann. Rep. N. Y. State Mus. 29: 43, 1878.

Fig. 2e

Pileus 40-105 $\mathrm{mm}$ in diam., convex at first, becoming nearly plane or subinfundibuliform, fleshy; surface glabrous, viscid when wet, somewhat zonate, pale blood red with a smoky hue when young, turning greenish with age or when bruised; margin curved when young, plane at maturity, sulcate, $\mathrm{KOH}$ test negative on cap surface. Lamellae adnate or decurrent, distant, brittle, lamellulae present in 2-3 tier, blood red when young, becoming spotted green with age. Stipe 30-55 × 9-24 $\mathrm{mm}$, equal to subclavate, silvery white ring at the juncture of lamellae and stipe, dark yellowish pink, light reddish brown, often with silvery luster at maturity. Latex deep red coloured. Sporedeposit yellowish white. Spores 7.5-10.5 $\times 5.5-8 \mu \mathrm{m}$, broadly ellipsoid to ellipsoid, ornamentation amyloid, up to $0.5 \mu \mathrm{m}$, composed of ridges forming incomplete reticulation (Fig. 3e). Habitat - a rare, solitary, scattered, sometimes gregarious lactarii found on soil under conifers in association with Cedrus deodara, Cupressus torulosa, with scattered trees of Pinus roxburghii and Abies pindrow. Edible but not consumed in Garhwal.

Specimens examined -Bharsar, 8 September 2007 (GUH M-25266) district Pauri Garhwal.

Lactarius volemus (Fr.) Fr. var. volemus, Epicr. Syst. Mycol.: 344, 1848.

Fig. $2 f$

Pileus $35-110 \mathrm{~mm}$ in diam., planoconvex, planoconcave or infundibuliform when mature with or without papilla; surface dry smooth, finally cracked when dry ochraceous to cinnamon, reddish orange, orange-brown or dark brick, sometimes pinkish buff or saffron at margin; margin incurved when young mostly regular, pilear surface turns olive with $\mathrm{KOH}$. Lamellae emarginate to slightly decurrent, rather broad, rather distant, pale cream to warm buff, with dark coloured spots when old or bruised. Stipe 55-70 × 6-20 mm, central, cylindric or slightly tapered towards base, glabrous, concolorous with the pileus or slightly darker towards base. Context very firm, pale cream to cream, turning pale brownish. Latex white, milky copious becoming brownish on exposure to air, staining tissues brown, with $\mathrm{KOH}$ turns orange. Taste mild delicious. Odour strong fish like. Spore deposit whitish. Spores 6-11 × 6.5-9 $\mu \mathrm{m}$, globose to subglobose; ornamentation amyloid, up to $0.8 \mu \mathrm{m}$, composed of ridges forming almost complete reticulum (Fig. 3f). Habitat - solitary, scattered to gregarious on humicolous soil in association with Quercus leucotrichophora, Myrica esculenta, Rhododendron arboreum and scattered Pinus roxburghii. Edible and consumed in Garhwal. Medicinally important. 


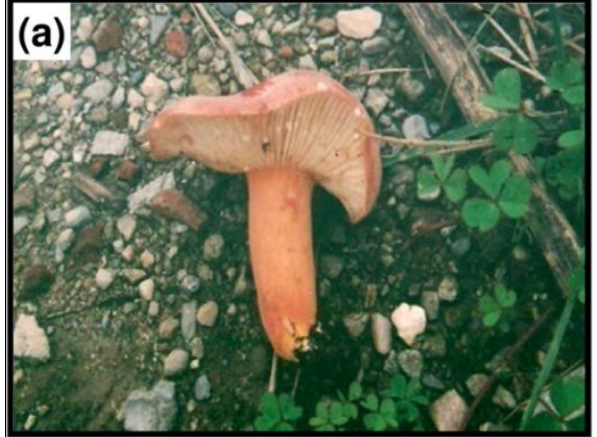

Lactarius hygrophoroides var. hygrophoroides

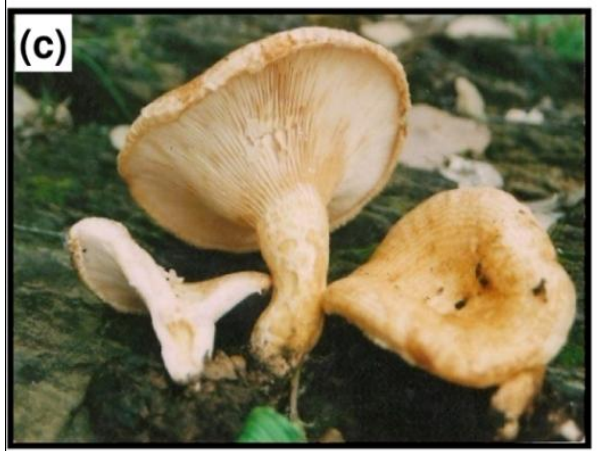

Lactarius scrobiculatus var. scrobiculatus

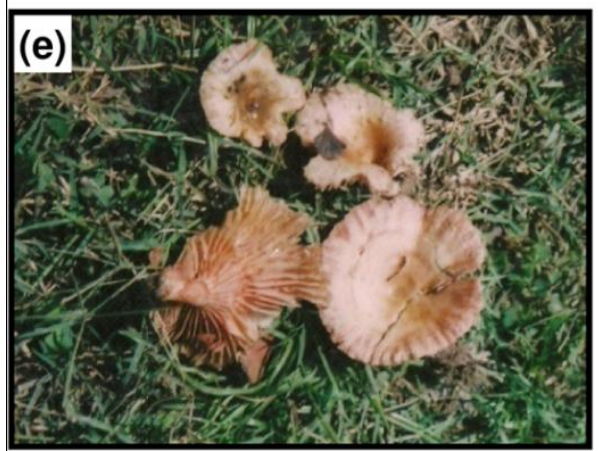

Lactarius subpurpureus

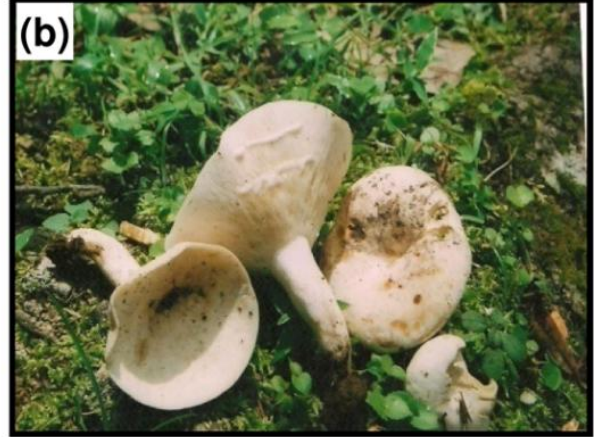

Lactarius piperatus var. piperatus

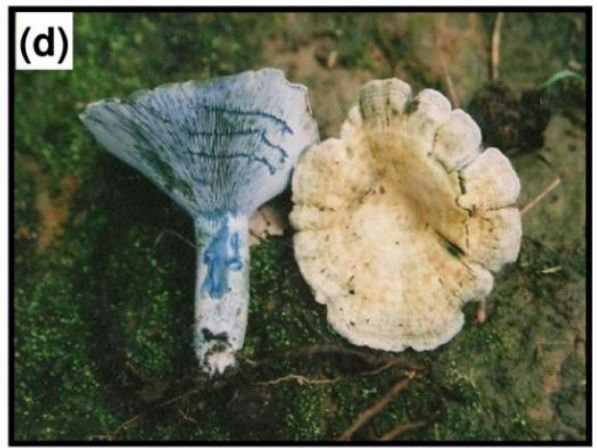

Lactarius subindigo

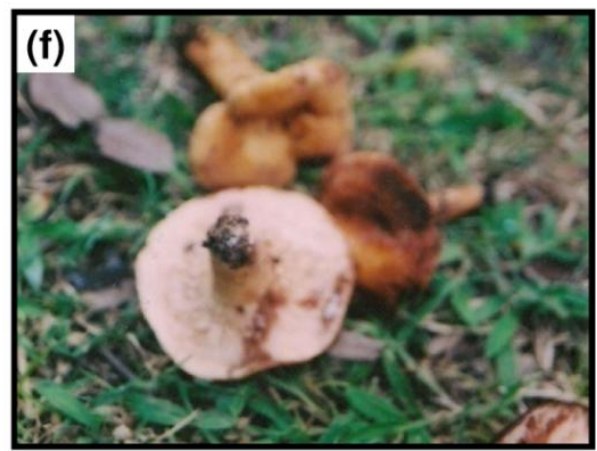

Lactarius volemus var. volemus

Fig. 2 - Samples of genus Lactarius collected from Garhwal Himalaya - a L. hygrophoroides var. hygrophoroides b $L$. piperatus var. piperatusc $L$. scrobiculatus var. scrobiculatusd $L$. subindigoe $L$. subpurpureusf L. volemus var. volemus

Specimens examined - Dandapani, 3 September 2008 (GUH M-25420) district Pauri Garhwal and Chandrabadni, 9 September 2009 (GUH M-25640) district Tehri Garhwal.

\section{Discussion}

Macro- and micro-climatic conditions of Garhwal Himalaya with appropriate temperature, adequate rainfall and soil $\mathrm{pH}$ are conditions which favors the growth of ectomycorrhizal genus Lactarius in the region. Most of the species reported are found in close association with Quercussp., Pinus sp., Rhododendron sp. and Cedrus sp. In monsoon season between the years 2006-2009 edible species of Lactarius (L. hygrophoroidesvar.hygrophoroides, L.scrobicualtus var. scrobiculatus, L. subindigo, L. subpurpureus and L. volemus var. volemus) were collected from district Pauri Garhwal and Tehri Garhwal. L. hygrophoroidesvar.hygrophoroides and L. volemus var. volemus species are consumed by locals of district Pauri Garhwal in Bubakhal, Chaubattakhal, Dandapani and in Chandrabadni of district Tehri Garhwal. L. subindigo collected from Khirsu and Surkanda devi is reported edible from other parts of the world (Boa 2004) but its consumption in 


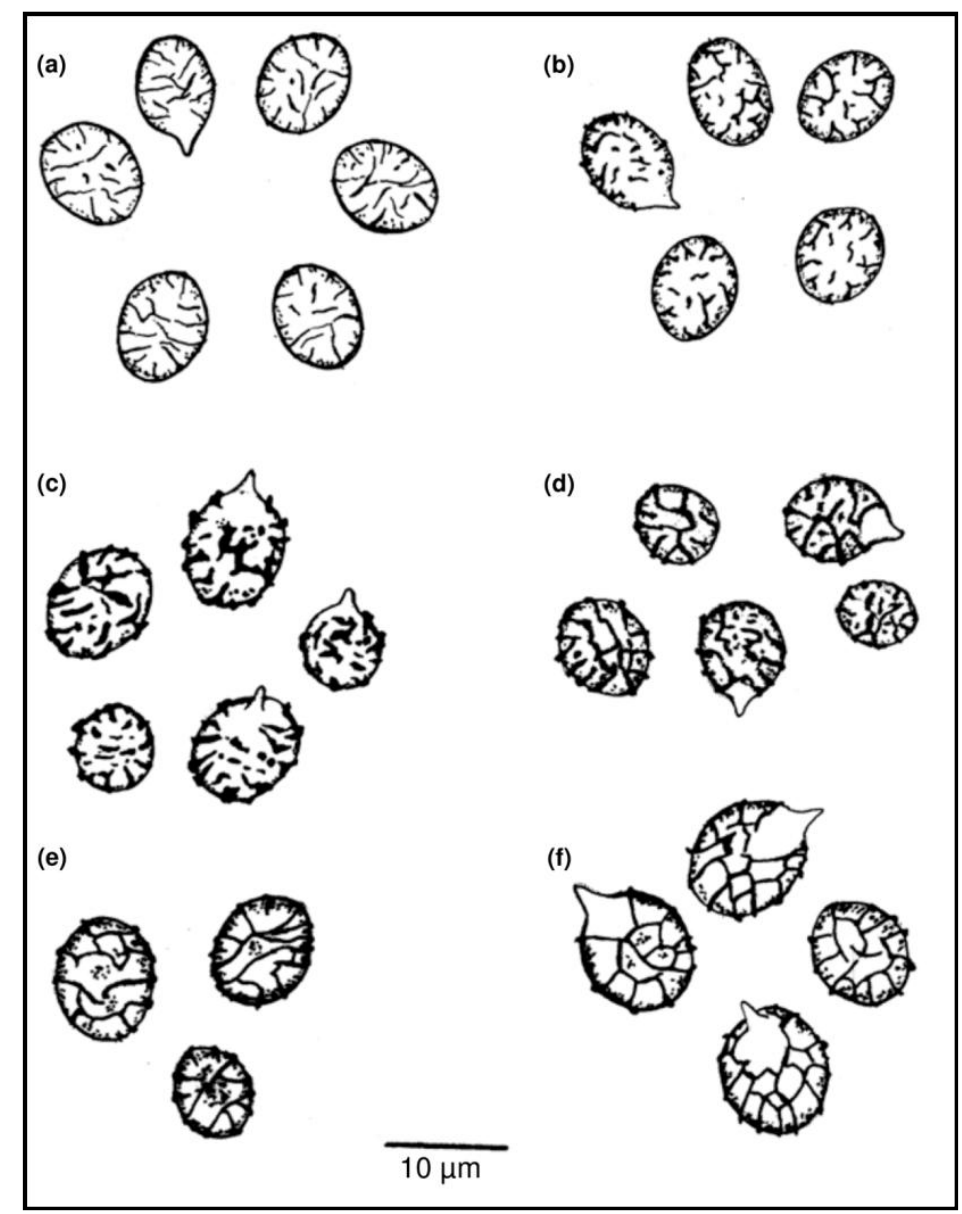

Fig. 3 - Microscopic spore characters of species collected - (a) Lactarius hygrophoroides var. hygrophoroides (b) L. piperatus var. piperatus(c) L. scrobiculatus var. scrobiculatus(d) $L$. subindigo(e) L. subpurpureus(f) L. volemus var. volemus.

Garhwal is not reported. L. subpurpureus collected from Bharsar is also reported edible from different parts of the world (Singer 1961, Kriger 1967, Lincoff 1981) but not consumed in Garhwal. However, in spite of reported edibility of these wild species, before picking these species for food proper identification and knowledge of collected specimen is a prerequisite condition. As with $L$. scrobiculatus var. scrobiculatus, which is found in Garhwal and consumed in many parts of the world (Singer 1961, Abraham et al. 1980, Boa 2004) after pickling is also on the other hand an indigestible species for many and causes irritation of gastrointestinal track (Miller 1981, Linchoff 1981).

L. volemus var. volemus and $L$. piperatus var. piperatus collected from Bharsar and Chandrabadni are medicinally important species collected from Garhwal. L. piperatus var. piperatus contains antioxidant ascorbic acid (Ferreria et al. 2009), while the chemical composition of $L$. volemus var. volemus has great medicinal value. It is a source of nutraceuticals, such as sugars, fatty acids and contains bioactive compounds like vitamins and phenolic acids (Reis et al. 2011). It is also reported to be active against Escherichia coli. Both are reported to contain important antioxidants that can be used for many oxidative stress related chronic diseases like cancer, Parkinson's disease, Alzheimer's disease, heart failure, Mycocardial infarction, Schizophrenia, Bipolar disorder, Sickle cell disease and Chronic fatigue syndrome.

These medicinally important and nutritionally rich edible species of Lactarius, if properly identified and characterized, can be used as a food source and medicinally important source. Fruiting bodies can be raised in liquid culture and culture medium can be manipulated to produce optimal quantities of active product for different pharmacological applications. 


\section{Acknowledgements}

This work was supported by a grant to Sweta Joshi from University Grants Commission of India. Authors thank Head, Department of Botany and Microbiology, HNB Garhwal University for providing all the required lab facilities.

\section{References}

Abraham SP, Kachroo JL, Kaul TN 1980 - Fleshy fungi of Gulmarg forest - 1. Kavaka 8, 29-39.

Boa ER, 2004 - Wild Edible Fungi: A global overview of their use and importance to people (NonWood Forest Products). FAO, Viale delle Terme di Caracalla. Rome, Italy.

Ferreira IC, Barros L, Abreu RM 2009 - Antioxidants in wild mushrooms. Current Medicinal Chemistry 16(12), 1543-1560.

Halling RE 1996 - Recommendations for collecting mushrooms. In: Selected Guidelines for Ethnobotanical Research: a field manual (ed. Alexiades MN). New York Botanical Garden, USA. 135-141.

Heilmann-Clausen J, Verbeken A, Vesterholt J 1998 - The Genus Lactarius. The Danish Mycological Society. Denmark.

Hesler LR, Smith AH 1979 - North American Species of Lactarius. The University of Michigan Press. USA.

Joshi S, Bhatt RP, Stephenson SL 2012 - The current status of the family Russulaceae in the Uttarakhand Himalaya, India. Mycosphere 3(4), 486-501.

Kriger LCC 1967 - The Mushrooms Hand Book, Dover Publications, New York.

Largent DL 1977a - How to Identify Mushrooms to Genus I. Macroscopic Features, Mad River Press, Eureka, CA. 86 p.

Largent DL, Johnson D, Watling R 1977b - How to Identify Mushrooms to Genus III. Microscopic Features, Mad River Press, Eureka, CA.

Linchoff GH 1981 - The Audubon Society Field Guide to North American Mushrooms. Alfred, A. Knopt, New York.

Miller OK Jr 1981 - Mushrooms of North -America. E.P. Dutton, New York.

Mlinaric A, Kac J, Fatur T, Filipic M 2004 - Anti-genotoxic activity of the mushroom Lactarius vellereus extract in bacteria and in mammalian cell in vitro. Pharmazie 59(3), 217-221.

Reis FS, Heleno SA, Barros L, Sousa MJ, Martins A, Santos-Buelga C, Ferreira IC 2011 - Toward the antioxidant and chemical characterization of mycorrhizal mushrooms from northeast Portugal. Journal of Food Science 76(6), C824-30.

Singer R 1949 - The Agaricales (Mushrooms) in Modern taxonomy. Lilloa 22, 472, 506. 832 p. 2nd edition from University of Tucuman, Argentina, August 1962.

Singer R 1961 - Mushrooms and Truffles. Interscience Publishers, New York.

Singer R. 1986 - The Agaricales in Modern Taxonomy. Bishen Singh Mahendrapal Singh, Dehradun, India. 981 pp. 88 plates.

Verbeken A, Walleyn R, Sharp C, Buyck B 2000 - Studies in tropical African Lactarius species 9. Records from Zimbabwe. Systematics and Geography of Plants 70, 181-215.

Wu Y, Wang H, Ng T 2012 - Purification and characterization of a novel RNase with antiproliferative activity from the mushroom Lactarius flavidulus. Journal of Antibiotics (Tokyo) 65(2), 67-72.

Zhang An-Ling, Liu La-Ping, Wang Min, Gao Jing Ming 2007 - Bioactive ergosterol derivatives isolated from the fungus Lactarius hatsudake. Chemistry of Natural Compounds 43(5), 637-638. 